\title{
Long-term effects of low-fat diets either low or high in protein on cardiovascular and metabolic risk factors: a systematic review and meta-analysis
}

\author{
Lukas Schwingshackl ${ }^{*}$ and Georg Hoffmann
}

\begin{abstract}
Background: Meta-analyses of short-term studies indicate favorable effects of higher protein vs. lower protein diets on health outcomes like adiposity or cardiovascular risk factors, but their long-term effects are unknown.

Methods: Electronic databases (MEDLINE, EMBASE, Cochrane Trial Register) were searched up to August 2012 with no restriction to language or calendar date. A random effect meta-analysis was performed using the Software package by the Cochrane Collaboration Review Manager 5.1. Sensitivity analysis was performed for RCTs with a Jadad Score $\geq 3$, and excluding type 2 diabetic subjects (T2D).

Results: 15 RCTs met all objectives and were included in the present meta-analysis. No significant differences were observed for weight, waist circumference, fat mass, blood lipids (i.e. total cholesterol, LDL-cholesterol, HDL-cholesterol, triacylglycerols), C-reactive protein, diastolic and systolic blood pressure, fasting glucose and glycosylated hemoglobin. In contrast, improvements of fasting insulin was significantly more pronounced following high protein diets as compared to the low protein counterparts (weighted mean difference: $-0.71 \mu \mathrm{lU} / \mathrm{ml}$, $95 \% \mathrm{Cl}-1.36$ to $-0.05, \mathrm{p}=0.03$ ). Sensitivity analysis of high quality $\mathrm{RCTs}$ confirmed the data of the primary analyses, while exclusion of studies with diabetic subjects resulted in an additional benefit of high-protein diets with respect to a more marked increase in $\mathrm{HDL}$-cholesterol.

Conclusion: According to the present meta-analysis of long-term RCTs, high-protein diets exerted neither specific beneficial nor detrimental effects on outcome markers of obesity, cardiovascular disease or glycemic control. Thus, it seems premature to recommend high-protein diets in the management of overweight and obesity.
\end{abstract}

Keywords: High-protein, Cardiovascular risk factors, Low-fat, Glycemic control

\section{Background}

With respect to the optimal macronutrient composition in the daily diet, most international authorities recommend to increase intakes of carbohydrates at the expense of fat and protein $[1,2]$. However, in face of the worldwide increase in prevalence of both overweight and obesity, there is a plethora of recommendations for diets aiming at weight loss and weight management. Among them, a high-protein (HP) regimen has gained increasing interest in recent years [3]. For the general population, recommended dietary reference intakes (DRIs) for protein are $0.66 \mathrm{~g} * \mathrm{~kg}$ body weight ${ }^{-1} * \mathrm{~d}^{-1}$ [4]. Actual consumption data for the US American population

\footnotetext{
* Correspondence: lukas.schwingshackl@univie.ac.at

Department of Nutritional Sciences, Faculty of Life Sciences, University of Vienna, Althanstraße 14 (UZII), Vienna A-1090, Austria
}

average $1.3 \mathrm{~g} * \mathrm{~kg}$ body weight ${ }^{-1} * \mathrm{~d}^{-1}$ in the $19-30$ age group indicating a protein intake in excess of their needs [5]. The Acceptable Macronutrient Distribution Range (AMDR) for protein is given as 5-35\% of daily calories depending on age [6]. A recent meta-analysis comparing HP vs. low-protein (LP) diets with a duration between 28 days and 12 months observed favorable effects of HP diets on biomarkers of obesity as well as cardiovascular risk factors such as HDL-cholesterol (HDL-C), triacylglycerols (TG), and blood pressure [7]. Several randomized controlled trials (RCTs) investigated the short-term effects of HP vs. LP diets, reporting advantages of HP protocols including a reduction in TG concentration [8-10]. A meta-regression of 87 studies concluded that low-carbohydrate, HP diets favorably affected body mass and composition independent of energy intake [11]. The benefits of HP diets might be

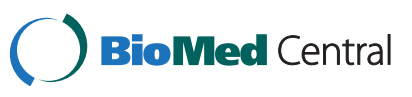


explained by increased thermogenesis and satiety [12,13]. Recent data from the 26-year follow up of the Nurses' Health Study (NHS) revealed that protein sources such as red meat and high-fat dairy products were significantly associated with an elevated risk of coronary heart disease, while higher intakes of poultry, fish, and nuts correlated with a lower risk of coronary heart disease (CHD) [14]. Since there is a lack of information concerning studies with different protein contents covering a longer dietary intervention period, the aim of this meta-analysis was to compare the long-term effects of HP vs. LP regimens on biomarkers of obesity, cardiovascular complications as well as adverse effects of HP.

\section{Methods}

The review protocol has been registered in PROSPERO International Prospective Register of Systematic Reviews (crd.york.ac.uk/prospero/index.asp Identifier: CRD42012002791).

\section{Literature search}

Literature search was performed using the electronic databases MEDLINE (between 1966 and August 2012), EMBASE (between 1980 and August 2012), and the Cochrane Trial Register (until August 2012) with restrictions to randomized controlled trials, but no restrictions to language and calender date using the following search term: (high protein diet). Moreover, the reference lists from retrieved articles were checked to search for further relevant studies. This systematic review was planned, conducted, and reported adhearing to standards of quality for reporting meta-analyses [15]. Literature search was conducted independently by both authors, with disagreements resolved by consensus.

\section{Eligibility criteria}

Studies were included in the meta-analysis if they met all of the following criteria: (1) randomized controlled design; (2) minimum intervention period with a followup of 12 months; (3) comparing a HP ( $\geq 25 \%$ of total energy content, TEC) with a LP dietary intervention ( $\leq 20 \%$ of TEC), with both protocols adopting a low fat diet ( $\leq 30 \%$ of TEC) [16]; (4) assessment of the outcome markers: weight, waist circumference (WC), fat mass (FM), total cholesterol (TC), low-density lipoprotein cholesterol (LDL-C), HDL-C, TG, diastolic and systolic blood pressure (DBP, SBP), C-reactive protein (CRP), fasting glucose (FG), fasting insulin (FI) and glycosylated hemoglobin (HbA1c); (5) report of post-intervention mean values (if not available mean of two time points were used) with standard deviation (or basic data to calculate these parameters). If data of ongoing studies were published as updates, results of only the longest duration periods were included.

\section{Quality assessment of studies}

Full copies of studies were independently assessed for methodological quality by both authors using the Jadad score [17]. This 5-point quality scale includes points for randomization (randomized $=1$ point; table of random numbers or computer generated randomization $=$ an additional 1 point), double-blinding (double-blind $=1$ point; use of a placebo = additional 1 point), and followup (numbers and reasons for withdrawal in each group are stated $=1$ point) within the report of an RCT. An additional point was accepted if the analysis was by intention-to-treat to compensate for the fact that double-blinded study protocols are elusive in dietary intervention studies. Final scores of $0-2$ were considered as low quality, while final scores of $\geq 3$ were regarded as representing studies of high quality. Furthermore, the trials were assessed for methodological quality using the risk of bias assessment tool by the Cochrane Collaboration [18] (Figure 1).

\section{Data extraction and statistical analysis}

The following data were extracted from each study: the first author's last name, publication year, study duration, participant's sex and age, BMI, \% diabetics, sample size, outcomes, drop outs and post mean values or differences in mean of two time point values with corresponding standard deviation. Subsequently, a standardized data extraction form for this systematic review was created according to Avenell et al. [19]. For each outcome measure of interest, a meta-analysis was performed in order to determine the pooled effect of the intervention in terms of weighted mean differences (WMDs) between the postintervention (or differences in means) values of the HP and LP groups. Combining both the post-intervention values and difference in means in one meta-analysis is a legitimate method described by the Cochrane Collaboration [20]. All data were analyzed using the REVIEW MANAGER 5.1 software, provided by the Cochrane Collaboration (http://ims.cochrane.org/revman). Heterogeneity between trial results was tested with a standard $x^{2}$ test. The $\mathrm{I}^{2}$ parameter was used to quantify any inconsistency: $I^{2}=[(Q-$ d.f. $)] / Q \times 100 \%$, where $Q$ is the $X^{2}$ statistic and d.f. is its degrees of freedom. A value for $\mathrm{I}^{2}>50 \%$ was considered to represent substantial heterogeneity [21]. To consider heterogeneity, the random-effects model was used to estimate WMDs with 95\% confidence intervals (CIs). Forest plots were generated to illustrate the studyspecific effect sizes along with a 95\% CI. Funnel plots were used to assess potential publication bias (e.g. the tendency for studies that yield statistically significant results to be more likely to be submitted and accepted for publication). To determine the presence of publication bias, the symmetry of the funnel plots in which mean differences were plotted against their corresponding standard errors was 


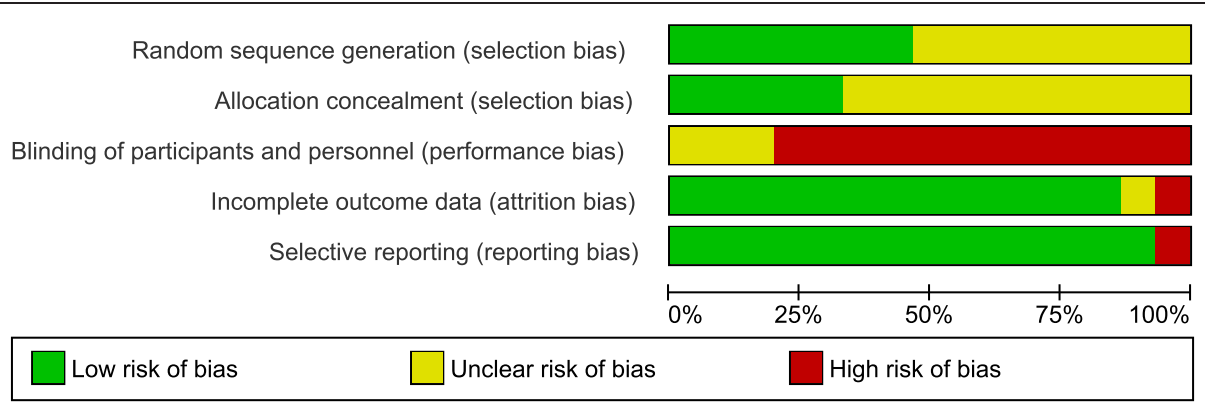

Figure 1 Risk of bias assessment tool. Across trials, information is either from trials at a low risk of bias (green), or from trials at unclear risk of bias (yellow), or from trials at high risk of bias (red).

assessed. One study [22] imputed two types of LP diets, and these diets were combined to one group as described in the Cochrane Handbook [20]. Data extraction was conducted independently by both authors, with disagreements resolved by consensus.

\section{Results}

Literature search and characteristic of studies

A total of 15 studies extracted from 3862 articles met the inclusion criteria and were analyzed in the systematic review [22-36]. The detailed steps of the metaanalysis article selection process are given as a flow chart in Figure 2. General study characteristics are given in Table 1. In case of more than one LP/LF group within a single study design, all LP interventions were combined as recommended by the Cochrane Collaboration [20]. Type 2 diabetes mellitus (T2D) was not defined as an exclusion criteria, and a total of three studies enrolling subjects with T2D were included in the present metaanalysis [24,32,33]. 13/15 studies reported the distribution of gender (1200 women vs. 690 men).

The pooled estimate of effect size for the effects of HP as compared to LP on primary and secondary outcomes are summarized in Table 2 .

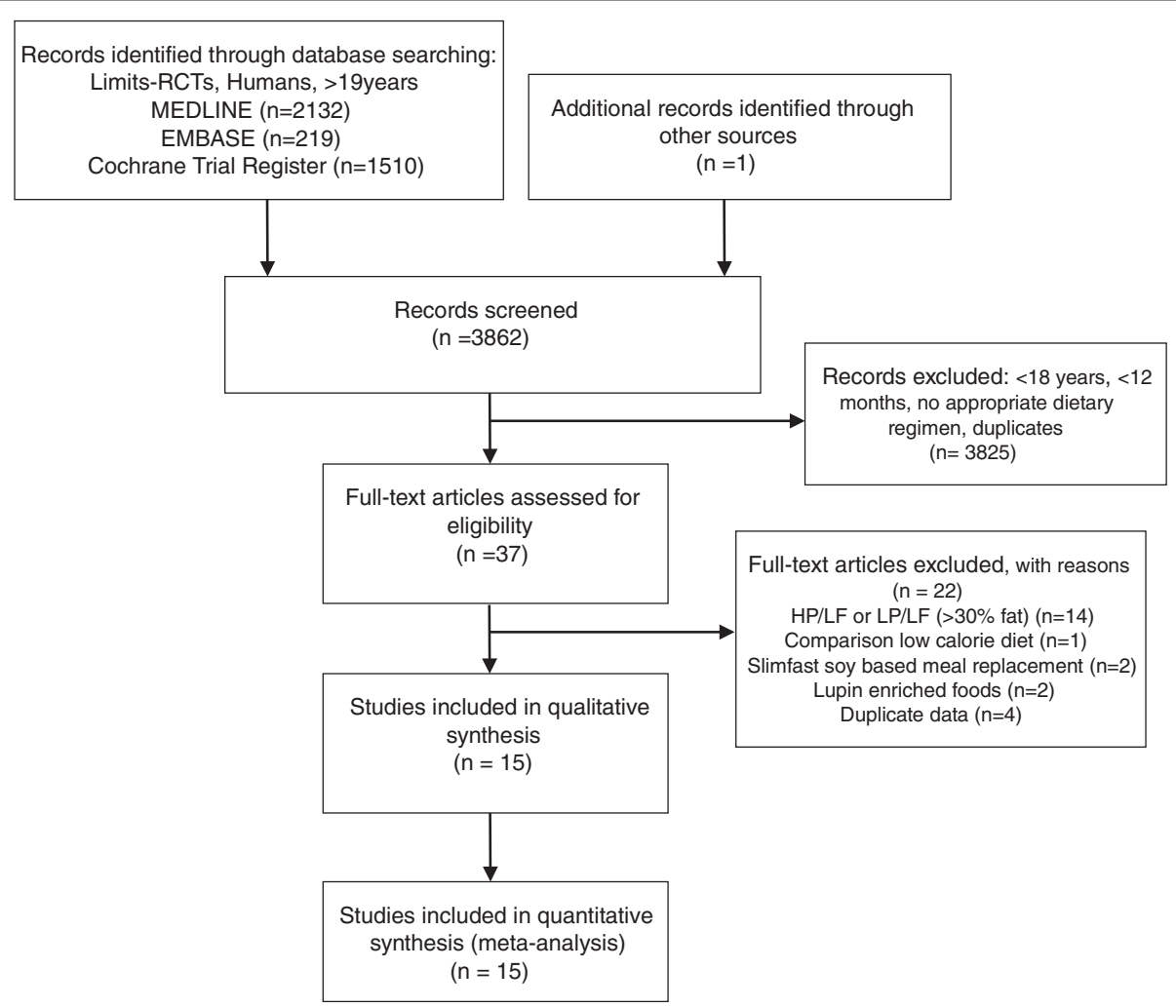

Figure 2 Flow diagram. 
Table 1 General characteristics of randomized controlled intervention trials included in the meta-analysis

\begin{tabular}{|c|c|c|c|c|c|c|c|c|}
\hline Reference & $\begin{array}{l}\text { Sample size, } \\
\text { BMI }\left(\mathrm{kg} / \mathrm{m}^{2}\right) \\
\% \text { diabetics }\end{array}$ & $\begin{array}{l}\text { Age, } \\
\text { Female (\%) } \\
\text { Male (\%) }\end{array}$ & $\begin{array}{l}\text { Duration, } \\
\text { months }\end{array}$ & $\begin{array}{l}\text { Dietary } \\
\text { intervention }\end{array}$ & $\begin{array}{l}\text { Dietary protocol } \\
\text { Protein(\%), } \\
\text { Carbohydrates(\%), } \\
\text { Fat(\%) }\end{array}$ & Energy restricted (kcal) & $\begin{array}{l}\text { Drop } \\
\text { Out }\end{array}$ & $\begin{array}{l}\text { Study } \\
\text { quality }\end{array}$ \\
\hline \multirow[t]{3}{*}{ Brinkworth et al. 2004 I [23] } & 58 & 50.2 & 16 & HP/LF vs. & $30 \%, 40 \%, 30 \%$ & $\begin{array}{l}1555 \text { (12 weeks), energy balance } \\
\text { (4 weeks), no restriction (follow up) }\end{array}$ & $27 \%$ & 2 \\
\hline & 34 & $77.5 \%$ & & LP/LF & $15 \%, 55 \%, 30 \%$ & 1555 (12 weeks), energy balance & $23 \%$ & \\
\hline & $0 \%$ & $22.5 \%$ & & & & & & \\
\hline \multirow[t]{3}{*}{ Brinkworth et al. 2004 || [24] } & 66 & $>60$ & 15 & HP/LF vs. & $30 \%, 40 \%, 30 \%$ & $\begin{array}{l}1600 \text { ( } 8 \text { weeks) energy balance } \\
\text { (4 weeks), no restriction (follow up) }\end{array}$ & $39 \%$ & 3 \\
\hline & $27-40$ & n.d & & LP/LF & $15 \%, 55 \%, 30 \%$ & 1600 (8 weeks) energy balance & $42 \%$ & \\
\hline & $100 \%$ & n.d & & & & & & \\
\hline \multirow[t]{3}{*}{ Clifton et al. 2007 [25] } & 79 & 49 & 15 & HP/LF vs. & $34 \%, 46 \%, 20 \%$ & $\begin{array}{l}1340 \text { ( } 12 \text { weeks), energy balance } \\
\text { (follow up, } 52 \text { weeks) }\end{array}$ & $29 \%$ & 2 \\
\hline & 32.8 & $100 \%$ & & $L P / L F$ & $17 \%, 64 \%, 20 \%$ & 1340 (12 weeks), energy balance & $38 \%$ & \\
\hline & $0 \%$ & $0 \%$ & & & & (follow up, 52 weeks) & & \\
\hline \multirow[t]{3}{*}{ Dansinger et al. 2005 [26] } & 80 & 49 & 12 & HP/LF vs. & $30 \%, 40 \%, 30 \%$ & no & $35 \%$ & 4 \\
\hline & 35 & $48 \%$ & & $L P / L F$ & $10-15 \%,>65 \%, 10 \%$ & no & $50 \%$ & \\
\hline & n.d & $52 \%$ & & & & & & \\
\hline \multirow[t]{3}{*}{ Das et al. 2007 [27] } & 34 & 35 & 12 & HP/LF vs. & $30 \%, 40 \%, 30 \%$ & 1900 & $18 \%$ & 2 \\
\hline & 27.6 & n.d & & LP/LF & $20 \%, 60 \%, 20 \%$ & 1960 & $12 \%$ & \\
\hline & $0 \%$ & n.d & & & & & & \\
\hline \multirow[t]{3}{*}{ Delbridge et al. 2009 [28] } & 141 & 44 & 12 & HP/LF vs. & $30 \%, 40 \%, 30 \%$ & no & $37 \%$ & 3 \\
\hline & 39 & $50 \%$ & & LP/LF & $15 \%, 55 \%, 30 \%$ & no & $41 \%$ & \\
\hline & n.d & $50 \%$ & & & & & & \\
\hline \multirow[t]{3}{*}{ Due et al. 2004[29] } & 50 & 39.6 & 12 & HP/LF vs. & $30 \%, 40 \%, 30 \%$ & no & $8 \%$ & 1 \\
\hline & 30.4 & $76 \%$ & & $L P / L F$ & $15 \%, 55 \%, 30 \%$ & no & $28 \%$ & \\
\hline & $0 \%$ & $24 \%$ & & & & & & \\
\hline \multirow[t]{3}{*}{ Gardner et al. 2007 [22] } & 232 & 40.6 & 12 & HP/LF vs. & $30 \%, 40 \%, 30 \%$ & yes & $23 \%$ & 4 \\
\hline & 31.33 & $100 \%$ & & $\mathrm{LP} / \mathrm{LF}^{*}$ & $10-15 \%, 55-70 \%, 10 / 30 \%$ & no/yes & $23 \%$ & \\
\hline & $0 \%$ & $0 \%$ & & & & & & \\
\hline \multirow[t]{3}{*}{ Keogh et al. 2007 [31] } & 25 & 48.7 & 12 & HP/LF vs. & $40 \%, 33 \%, 27 \%$ & 1435 & n.d & 1 \\
\hline & 32.9 & $68 \%$ & & LP/LF & $20 \%, 60 \%, 20 \%$ & 1435 & n.d & \\
\hline & $0 \%$ & $32 \%$ & & & & & & \\
\hline \multirow[t]{3}{*}{ Krebs et al. 2012 [32] } & 419 & 57.9 & 24 & HP/LF vs. & $30 \%, 40 \%, 30 \%$ & -500 & $30 \%$ & 4 \\
\hline & 36.6 & $60 \%$ & & LP/LF & $15 \%, 55 \%, 30 \%$ & -500 & $24 \%$ & \\
\hline & $100 \%$ & $40 \%$ & & & & & & \\
\hline \multirow[t]{3}{*}{ Larsen et al. 2011 [33] } & 99 & 59.2 & 12 & HP/LF vs. & $30 \%, 40 \%, 30 \%$ & $\begin{array}{l}1530 \text { ( } 3 \text { months), energy balance } \\
\text { (follow up) }\end{array}$ & $19 \%$ & 4 \\
\hline & $27-40$ & $52 \%$ & & $L P / L F$ & $15 \%, 55 \%, 30 \%$ & 1530 (3 months), energy balance & $20 \%$ & \\
\hline & $100 \%$ & $48 \%$ & & & & & & \\
\hline \multirow[t]{3}{*}{ Layman et al. 2008 [30] } & 130 & 45.4 & 12 & HP/LF vs. & $30 \%, 40 \%, 30 \%$ & 1700 women, 1900 men & $36 \%$ & 2 \\
\hline & 32.6 & $55 \%$ & & LP/LF & $15 \%, 55 \%, 30 \%$ & 1700 women, 1900 men & $55 \%$ & \\
\hline & n.d & $45 \%$ & & & & & & \\
\hline \multirow[t]{3}{*}{ McAuley et al. 2006 [34] } & 48 & n.d & 12 & HP/LF vs. & $30 \%, 40 \%, 30 \%$ & no & $7 \%$ & 2 \\
\hline & n.d & $100 \%$ & & LP/LF & $15 \%, 55 \%, 30 \%$ & no & $25 \%$ & \\
\hline & Insulin resistant & $0 \%$ & & & & & & \\
\hline \multirow[t]{3}{*}{ Sacks et al. 2009 [35] } & 406 & 50.5 & 24 & HP/LF vs. & $25 \%, 55 \%, 20 \%$ & -750 & $22 \%$ & 4 \\
\hline & 33 & $64 \%$ & & LP/LF & $15 \%, 65 \%, 20 \%$ & -750 & $16 \%$ & \\
\hline & $0 \%$ & $36 \%$ & & & & & & \\
\hline
\end{tabular}


Table 1 General characteristics of randomized controlled intervention trials included in the meta-analysis (Continued)

\begin{tabular}{llllllll}
\hline Wycherley et al. 2012 [36] & 123 & $20-65$ & 12 & HP/LF vs. & $35 \%, 40 \%, 25 \%$ & 1700 & 4 \\
& $27-40$ & $0 \%$ & & LP/LF & $17 \%, 58 \%, 25 \%$ & 1700 & $44 \%$ \\
& $0 \%$ & $100 \%$ & & & & & \\
\hline
\end{tabular}

"two kind of LP/LF diets (very LF: $10 \%$ and LF: $30 \%$ of total energy content).

$\mathrm{HP}$, high-protein; LF, low fat; LP, low-protein; n.d, no data.

Data analysis

\section{Weight/ Waist circumference/ Fat Mass}

Weighted mean differences (WMD) in change of weight [ $-0.39 \mathrm{~kg}$ (95\% CI -1.43 to 0.65$), \mathrm{p}=0.46]$, WC $[-0.98 \mathrm{~cm}$ (95\% CI -3.32 to 1.37$), \mathrm{p}=0.41]$ and FM $[-0.59 \mathrm{~kg}(95 \%$ $\mathrm{CI}-\mathrm{-1.32}$ to 0.13$), \mathrm{p}=0.11]$ were not statistically significant when comparing HP vs. LP dietary protocols.

\section{Serum lipids}

No significant changes were observed for TC [WMD: $2.51 \mathrm{mg} / \mathrm{dl}$ (95\% CI -7.74 to 2.71$), \mathrm{p}=0.35]$, LDL cholesterol [WMD: $1.58 \mathrm{mg} / \mathrm{dl}$ (95\% CI -5.36 to 8.53 ), $\mathrm{p}=0.66$ ], HDL cholesterol [WMD: $0.90 \mathrm{mg} / \mathrm{dl} \quad(95 \%$ $\mathrm{CI}-0.09$ to 1.89$), \mathrm{p}=0.08$ ], and TG [WMD: $-2.87 \mathrm{mg} / \mathrm{dl}$ (95\% CI -11.13 to 5.38$), \mathrm{p}=0.49$ ] between $\mathrm{HP}$ and LP diets.

\section{Blood Pressure/CRP}

When comparing HP and LP regimen, no significant differences could be found with respect to WMDs in change of CRP $[0.22 \mathrm{mg} / \mathrm{dl}$ (95\% CI -0.36 to 0.79 ), $\mathrm{p}=0.46$ ] and blood pressure values [DBP: $-0.42 \mathrm{mmHg}$ (95\% CI -1.37 to 0.54 ), $\mathrm{p}=0.39$; and SBP: $-1.61 \mathrm{mmHg}$ (95\% CI -3.45 to 0.23 ), $\mathrm{p}=0.09]$.

\section{Glycemic control}

Decreases in FI were significantly more explicit in subjects adhering to an HP diet as compared to those following an LP regimen [WMD: $-0.71 \mu \mathrm{IU} / \mathrm{ml}$ (95\% $\mathrm{CI}-1.36$ to -0.05 ), $\mathrm{p}=0.03$ ] (Figure 3 ). None-significant changes were observed for FG [WMD: $-0.63 \mathrm{mg} / \mathrm{dl}(95 \%$ $\mathrm{CI}-1.93$ to 0.67$), \mathrm{p}=0.34$ ], and HbA1c [WMD: $0.07 \%$ (95\% CI -0.17 to 0.31 ), $\mathrm{p}=0.55]$.

\section{Sensitivity analysis}

Articles with a Jadad quality score $\geq 3$ only were included in the sensitivity analyses. A total of $8 / 15$ studies remained for sensitivity analyses [22,24,26,28,32,33,35,36]. The results of the primary analyses could be confirmed for all the parameters that were not significantly altered in different ways in the HP and LP groups. Furthermore, changes in FI turned out to be of similar dimension as well when studies with poor Jadad scores were excluded. In an additional sensitivity analysis, studies enrolling patients with T2D $[33,34,36]$ were discarded to account for a potential "reproducibility effect" on the pooled WMD when comparing the results of the present systematic review with a meta-analysis by Santesso et al. [7], where T2D represented an exclusion criterium. Results were not significantly different as compared to the comprehensive meta-analyses

Table 2 Pooled estimates of effect size ( $95 \%$ confidence intervals) expressed as weighted mean difference for the effects of HP vs. LP diets on cardiovascular and metabolic risk factors

\begin{tabular}{|c|c|c|c|c|c|c|}
\hline Outcomes & No. of studies & Participants & WMD & $95 \% \mathrm{Cl}$ & p-values & Inconsistency I $^{2}$ \\
\hline Weight (kg) & 13 & 971 & -0.39 & {$[-1.43,0.65]$} & 0.46 & $0 \%$ \\
\hline WC $(\mathrm{cm})$ & 8 & 727 & -0.98 & {$[-3.32,1.37]$} & 0.41 & $72 \%$ \\
\hline $\mathrm{FM}(\mathrm{kg})$ & 10 & 913 & -0.59 & {$[-1.32,0.13]$} & 0.11 & $0 \%$ \\
\hline $\mathrm{TC}(\mathrm{mg} / \mathrm{dl})$ & 12 & 1251 & -2.51 & {$[-7.74,2.71]$} & 0.35 & $32 \%$ \\
\hline LDL-C (mg/dl) & 13 & 1522 & 1.58 & {$[-5.36,8.53]$} & 0.66 & $79 \%$ \\
\hline HDL-C (mg/dl) & 14 & 1563 & 0.90 & {$[-0.09,1.89]$} & 0.08 & $0 \%$ \\
\hline TG (mg/dl) & 14 & 1563 & -2.87 & {$[-11.13,5.38]$} & 0.49 & $21 \%$ \\
\hline $\mathrm{DBP}(\mathrm{mmHg})$ & 11 & 1402 & -0.42 & {$[-1.37,0.54]$} & 0.39 & $0 \%$ \\
\hline $\mathrm{SBP}(\mathrm{mmHg})$ & 11 & 1414 & -1.61 & {$[-3.45,0.23]$} & 0.09 & $41 \%$ \\
\hline CRP (mg/dl) & 4 & 222 & 0.22 & {$[-0.36,0.79]$} & 0.46 & $0 \%$ \\
\hline $\mathrm{FG}(\mathrm{mg} / \mathrm{dl})$ & 11 & 1357 & -0.63 & {$[-1.93,0.67]$} & 0.34 & $0 \%$ \\
\hline $\mathrm{FI}(\mu \mathrm{lU} / \mathrm{ml})$ & 11 & 1086 & -0.71 & {$[-1.36,-0.05]$} & 0.03 & $0 \%$ \\
\hline HbA1c (\%) & 3 & 431 & 0.07 & {$[-0.17,0.31]$} & 0.55 & $0 \%$ \\
\hline
\end{tabular}

$\mathrm{Cl}$, confidence intervalls, CRP, high-sensitive- $\mathrm{C}$ reactive protein; $\mathrm{DBP}$, diastolic blood pressure; FG, fasting glucose; $\mathrm{Fl}$, fasting insulin; $\mathrm{FM}$, fat mass; $\mathrm{HbA1C}$, glycosylated hemoglobin; HDL-C, high-density lipoprotein cholesterol; LDL-C, low-density lipoprotein cholesterol; SBP, systolic blood pressure; TC, total cholesterol, TG, triacyglycerols; WC, waist circumference; WMD, weighted mean difference. 
except for one parameter, i.e. the beneficial increase in HDL-C was more pronounced in the HP as compared to the LP diet [WMD: $1.50 \mathrm{mg} / \mathrm{dl}$ (95\% CI 0.37 to 2.62$), \mathrm{p}=$ 0.009] (Figure 4).

\section{Publication bias}

The funnel plots (with respect to effect size changes for Weight, WC, FM, TC, LDL-C, HDL-C, TG, CRP, DBP, SBP, FG, FI and HbA1c in response to HP diets) indicates little to moderate asymmetry, suggesting that publication bias cannot be completely excluded as a factor of influence on the present meta-analysis. It remains possible that small studies yielding inconclusive data have not been published.

\section{Heterogeneity}

Considerable heterogeneity was found with respect to WC $\left(\mathrm{I}^{2}=72 \%\right)$ and LDL-C $\left(\mathrm{I}^{2}=79 \%\right)$ in the primary analysis. Moderate heterogeneity was observed for $\mathrm{TC}\left(\mathrm{I}^{2}=32 \%\right)$ and SBP $\left(\mathrm{I}^{2}=41 \%\right)$, the other outcomes showed low heterogeneity $\left(\mathrm{I}^{2}=0-21 \%\right)$.

\section{Discussion}

In this systematic review, HP dietary protocols were compared with LP regimens with respect to their effects on biomarkers of obesity and obesity-associated disorders such as diabetes or cardiovascular disease. Analyses were restricted on $\mathrm{HP}$ as well as LP diets providing $\leq$ $30 \%$ of TEC in the form of fat to prevent potential bias due to variations in total fat intake. Main findings suggest no advantages or disadvantages of a higher dietary protein content. None of the dietary protocols turned out to be superior to its counterpart with regard to the biomarkers under investigation. Following primary analysis, decreases in fasting insulin were significantly more pronounced in HP diets. However, this was no longer valid after inclusion of high quality trials only in the secondary analysis. The raise in HDL-C turned out to be more pronounced in the HP group compared to the LP group following sensitivity analysis excluding studies that enrolled patients with T2D. In a previous study, HP diets exerted a 12\%-increase in HDL-C under closely

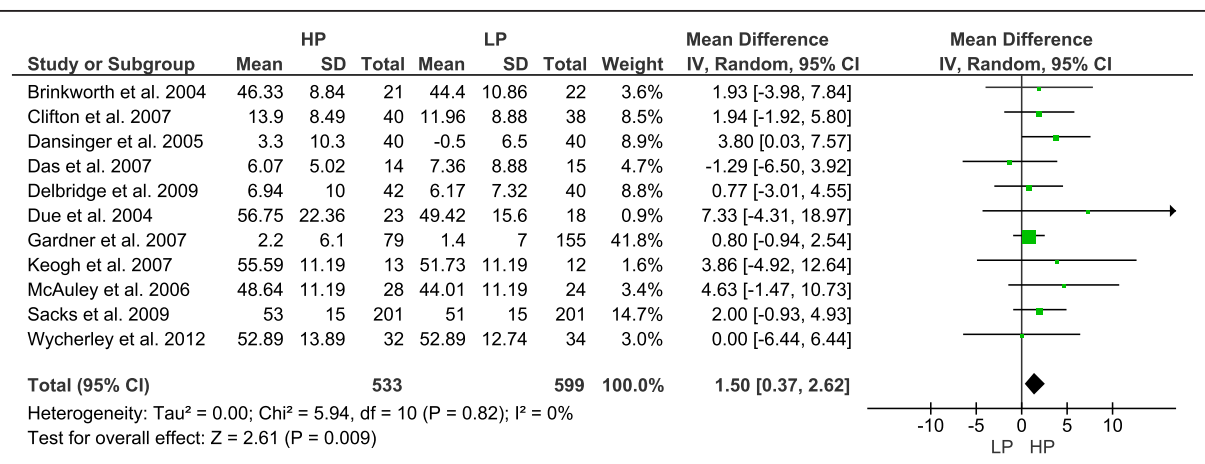

Figure 4 Forest plot showing pooled WMD with $95 \% \mathrm{Cl}$ for HDL-cholesterol (mg/dl) for 10 randomized controlled high-protein diet studies (excluding T2D subjects). For each high-protein study, the shaded square represents the point estimate of the intervention effect. The horizontal line joins the lower and upper limits of the $95 \% \mathrm{Cl}$ of these effects. The area of the shaded square reflects the relative weight of the study in the respective meta-analysis. The diamond at the bottom of the graph represents the pooled WMD with the $95 \% \mathrm{Cl}$ for the 10 study groups. Abbreviations: HP = high-protein; LP = low-protein; $\mathrm{I}^{2}=$ Inconsistency; T2D = type 2 diabetes. 
supervised dietary control [37]. Two meta-analyses provide evidence that higher fat intake was associated with higher levels of HDL-C when compared to low-fat diets $[38,39]$. With respect to the studies included in the present systematic review, the trials by Gardner et al. [22], Dansinger et al. [26], and McAuley et al. [34] reported higher intakes of total fat at the end of their 12 months protocols (dietary records) in the HP groups as compared to the respective LP counterparts. Omitting these trials to the sensitivity analysis, changes in HDL-C turned out to be similar in both HP and LP regimen (data not shown), suggesting that HDL-C response was due to dietary fat content rather than to protein consumption.

Taken together, these results are in discrepancy with a recent meta-analysis by Santesso and co-workers [7] who reported weight loss, WC, HDL-C, TG, SBP, DBP and FI to be significantly more improved following short-and long-term HP diets as compared to LP protocols. The different findings might at least in part be explained by the fact that only long-term studies with a duration $\geq 12$ months were included in the present meta-analysis. In addition, both post-intervention values as well as changes in mean differences were used as suggested by the Cochrane Collaboration [20] to avoid a standardized mean differences method, whereas Santesso et al. [7] separated between primary (change from baseline values) and secondary (final values) analyses. These results indicate that HP diets do not exert favorable effects on anthropometric measures like body weight, fat mass and waist circumference. However, in a meta-regression by Krieger et al. [11] high-protein intake turned out to be a significant predictor of fat free mass retention, thereby compensating a potential side-effect of long-term energy restriction.

Dietary protein content of the high-protein diets included in this meta-analysis varied between $30-40 \%$ of TEC, which is within the age-dependent AMDR of 5-35\% for all but one RCT [31]. Via analysis of the National Health and Nutrition Examinations Survey conducted between 2003 and 2004, Fulgoni [5] concluded that the actual intake of protein in US-American adults of $1.3 \mathrm{~g} * \mathrm{~kg}$ body weight ${ }^{-1} * \mathrm{~d}^{-1}$ exceeds the DRI values of $0.66 \mathrm{~g} * \mathrm{~kg}$ body weight ${ }^{-1} * \mathrm{~d}^{-1}$. He suggested that recommendations could be adapted to $25-30 \%$ of TEC, assuming benefits of higher protein intake e.g. on regulation of body weight. Regarding biomarkers such as weight, waist circumference or fat mass, the present meta-analysis does not support this concept.

Three RCTs included in this meta-analysis investigated the effects of HP regimens on biomarkers of kidney function in patients with T2D. In all trials, HP diets did not affect renal functions assessed via measurement of serum creatinine and microalbuminurea [32,33,36]. Likewise, a 2-year RCT by Friedman et al. [40] reported no harmful effects of a high-protein/low carbohydrate diet on glomerular filtration rate, albuminuria, or fluid and electrolyte balance. With respect to prospective cohort studies, a systematic review by Mente et al. [41] indicated no significant correlations between animal protein sources, e.g. eggs, milk or meat on coronary heart disease (CHD), whereas vegetable protein sources like nuts were associated with a decreased risk. Findings from Greece, Sweden and the US noted an increased all-cause mortality following a HP/low carbohydrate diet based on animal sources in both women and men whereas a vegetable-based low-carbohydrate diet was associated with lower all-cause and cardiovascular disease mortality rates [42-44].

This systematic review did not consider unpublished data, and with respect to the moderate asymmetry of the Funnel plots, it cannot be excluded that publication bias such as lack of published studies with inconclusive results may have at least a moderate impact on the effect size estimates. An important limitation of dietary intervention trials is the heterogeneity of various aspects and characteristics of the study protocols. The literature chosen for the present meta-analysis varies regarding type(s) of diets used, definitions of HP and LP diets, study population (i.e. BMI, type 2 diabetics, abnormal glucose metabolism), intervention time, nutritional assessment as well as longterm follow-ups (between 1 and 2 yrs.). In addition, some studies were performed on hypocaloric terms, while others provided an isocaloric diet.

Not all of the studies gave details on the quality of their respective setup (e.g. method of randomization, follow-up protocol with reasons for withdrawal) yielding Jadad scores $<3$. However, following sensitivity analyses including high quality studies only (Jadad score $\geq 3$ ), pooled estimates of effect size were similar to those obtained with the complete set of studies. Some comparisons within the present meta-analyses were done using both post-intervention values and changes in mean difference, which is considered to be a legitimate procedure as described by the Cochrane Collaboration [20], and should not be regarded as a limitation.

In summary, the present meta-analysis investigated the long-term effects of HP vs. LP both low in fat on biomarkers predicting the outcome of obesity, cardiovascular disease and glycemic control. Since biomarkers under investigation were not affected by changes in dietary protein content, unanimous recommendation of a highprotein dietary approach is not supported by evidence. With respect to the potential risk of high-protein contents, further studies are required before dietary recommendations can be changed towards a higher percentage of daily protein consumption.

Competing interests

Both Author declare that they have no competing interest. 


\section{Authors' contributions}

LS and GH conducted the data analysis, interpretation of results, manuscript drafting, and finalizing manuscript. All authors read and approved the final manuscript.

Received: 29 October 2012 Accepted: 10 April 2013 Published: 15 April 2013

\section{References}

1. Krauss RM, Eckel RH, Howard B, Appel LJ, Daniels SR, Deckelbaum RJ Erdman JW Jr, Kris-Etherton P, Goldberg IJ, Kotchen TA, et al: AHA Dietary Guidelines: revision 2000: A statement for healthcare professionals from the Nutrition Committee of the American Heart Association. Circulation 2000, 102:2284-2299.

2. Abete I, Astrup A, Martinez JA, Thorsdottir I, Zulet MA: Obesity and the metabolic syndrome: role of different dietary macronutrient distribution patterns and specific nutritional components on weight loss and maintenance. Nutr Rev 2010, 68:214-231.

3. Farnsworth E, Luscombe ND, Noakes M, Wittert G, Argyiou E, Clifton PM: Effect of a high-protein, energy-restricted diet on body composition, glycemic control, and lipid concentrations in overweight and obese hyperinsulinemic men and women. Am J Clin Nutr 2003, 78:31-39.

4. National Academy of Sciences. Institute of Medicine Food and Nutrition Board. http://www.iom.edu/Activities/Nutrition/SummaryDRIs/ /media/Files/ Activity\%20Files/Nutrition/DRIs/5_Summary\%20Table\%20Tables\%201-4.pdf (accessed March 2013).

5. Fulgoni VL 3rd: Current protein intake in America: analysis of the National Health and Nutrition Examination Survey, 2003-2004. Am J Clin Nutr 2008, 87:1554S-1557S.

6. Food and Nutrition Board loM: In Dietary reference intakes for energy, carbohydrates, fiber, fatty acids, cholesterol, protein, and amino acids (macronutrients). Edited by Washington DNAP. 2002:207-264.

7. Santesso N, Akl EA, Bianchi M, Mente A, Mustafa R, Heels-Ansdell D, Schunemann $\mathrm{HJ}$ : Effects of higher- versus lower-protein diets on health outcomes: a systematic review and meta-analysis. Eur J Clin Nutr 2012, 66:780-788

8. Noakes M, Keogh JB, Foster PR, Clifton PM: Effect of an energy-restricted, high-protein, low-fat diet relative to a conventional high-carbohydrate, low-fat diet on weight loss, body composition, nutritional status, and markers of cardiovascular health in obese women. Am J Clin Nutr 2005, 81:1298-1306.

9. Skov AR, Toubro S, Ronn B, Holm L, Astrup A: Randomized trial on protein vs carbohydrate in ad libitum fat reduced diet for the treatment of obesity. Int J Obes Relat Metab Disord 1999, 23:528-536.

10. Layman DK, Boileau RA, Erickson DJ, Painter JE, Shiue H, Sather C, Christou DD: A reduced ratio of dietary carbohydrate to protein improves body composition and blood lipid profiles during weight loss in adult women. J Nutr 2003, 133:411-417.

11. Krieger JW, Sitren HS, Daniels MJ, Langkamp-Henken B: Effects of variation in protein and carbohydrate intake on body mass and composition during energy restriction: a meta-regression 1. Am J Clin Nutr 2006, 83:260-274.

12. Halton $T L, H u F B$ : The effects of high protein diets on thermogenesis, satiety and weight loss: a critical review. J Am Coll Nutr 2004, 23:373-385.

13. Clifton PM, Keogh J: Metabolic effects of high-protein diets. Curr Atheroscler Rep 2007, 9:472-478.

14. Bernstein AM, Sun Q, Hu FB, Stampfer MJ, Manson JE, Willett WC: Major dietary protein sources and risk of coronary heart disease in women. Circulation 2010, 122:876-883.

15. Moher D, Liberati A, Tetzlaff J, Altman DG: Preferred reporting items for systematic reviews and meta-analyses: the PRISMA statement. PLoS Med 2009, 6:e1000097.

16. Lepe M, Bacardi Gascon M, Jimenez Cruz A: Long-term efficacy of high-protein diets: a systematic review. Nutr Hosp 2011, 26:1256-1259.

17. Jadad AR, Moore RA, Carroll D, Jenkinson C, Reynolds DJ, Gavaghan DJ, McQuay $\mathrm{HJ}$ : Assessing the quality of reports of randomized clinical trials: is blinding necessary? Control Clin Trials 1996, 17:1-12

18. Higgins JP, Altman DG, Gotzsche PC, Juni P, Moher D, Oxman AD, Savovic J, Schulz KF, Weeks L, Sterne JA: The Cochrane Collaboration's tool for assessing risk of bias in randomised trials. BMJ 2011, 343:d5928.
19. Avenell A, Broom J, Brown TJ, Poobalan A, Aucott L, Stearns SC, Smith WC, Jung RT, Campbell MK, Grant AM: Systematic review of the long-term effects and economic consequences of treatments for obesity and implications for health improvement. Health Technol Assess 2004, 8:iii-iv:1-182.

20. Higgins JP, Green S: Cochrane Handbook of systematic reviews, Version 5.1.0. 2011. updated March http:/handbook.cochrane.org/ (accessed August 2012).

21. Higgins JP, Thompson SG, Deeks JJ, Altman DG: Measuring inconsistency in meta-analyses. BMJ 2003, 327:557-560.

22. Gardner CD, Kiazand A, Alhassan S, Kim S, Stafford RS, Balise RR, Kraemer $\mathrm{HC}$, King AC: Comparison of the Atkins, Zone, Ornish, and LEARN diets for change in weight and related risk factors among overweight premenopausal women: the A TO Z Weight Loss Study: a randomized trial. JAMA 2007, 297:969-977.

23. Brinkworth GD, Noakes M, Keogh JB, Luscombe ND, Wittert GA, Clifton PM: Long-term effects of a high-protein, low-carbohydrate diet on weight control and cardiovascular risk markers in obese hyperinsulinemic subjects. Int J Obes Relat Metab Disord 2004, 28:661-670.

24. Brinkworth GD, Noakes M, Parker B, Foster P, Clifton PM: Long-term effects of advice to consume a high-protein, low-fat diet, rather than a conventional weight-loss diet, in obese adults with type 2 diabetes: oneyear follow-up of a randomised trial. Diabetologia 2004, 47:1677-1686.

25. Clifton PM, Keogh JB, Noakes M: Long-term effects of a high-protein weight-loss diet. Am J Clin Nutr 2008, 87:23-29.

26. Dansinger ML, Gleason JA, Griffith JL, Selker HP, Schaefer EJ: Comparison of the Atkins, Ornish, Weight Watchers, and Zone diets for weight loss and heart disease risk reduction: a randomized trial. JAMA 2005, 293:43-53.

27. Das SK, Gilhooly CH, Golden JK, Pittas AG, Fuss PJ, Cheatham RA, Tyler S, Tsay M, McCrory MA, Lichtenstein AH, et al: Long-term effects of 2 energyrestricted diets differing in glycemic load on dietary adherence, body composition, and metabolism in CALERIE: a 1-y randomized controlled trial. Am J Clin Nutr 2007, 85:1023-1030

28. Delbridge EA, Prendergast LA, Pritchard JE, Proietto J: One-year weight maintenance after significant weight loss in healthy overweight and obese subjects: does diet composition matter? Am J Clin Nutr 2009, 90:1203-1214.

29. Due A, Toubro S, Skov AR, Astrup A: Effect of normal-fat diets, either medium or high in protein, on body weight in overweight subjects: a randomised 1-year trial. Int J Obes Relat Metab Disord 2004, 28:1283-1290.

30. Layman DK, Evans EM, Erickson D, Seyler J, Weber J, Bagshaw D, Griel A, Psota T, Kris-Etherton P: A moderate-protein diet produces sustained weight loss and long-term changes in body composition and blood lipids in obese adults. J Nutr 2009, 139:514-521.

31. Keogh JB, Brinkworth GD, Clifton PM: Effects of weight loss on a lowcarbohydrate diet on flow-mediated dilatation, adhesion molecules and adiponectin. Br J Nutr 2007, 98:852-859.

32. Krebs JD, Elley CR, Parry-Strong A, Lunt H, Drury PL, Bell DA, Robinson E, Moyes SA, Mann J: The Diabetes Excess Weight Loss (DEWL) Trial: a randomised controlled trial of high-protein versus high-carbohydrate diets over 2 years in type 2 diabetes. Diabetologia 2012, 55:905-914.

33. Larsen RN, Mann NJ, Maclean E, Shaw JE: The effect of high-protein, low-carbohydrate diets in the treatment of type 2 diabetes: a 12 month randomised controlled trial. Diabetologia 2011, 54:731-740.

34. McAuley KA, Smith KJ, Taylor RW, McLay RT, Williams SM, Mann Jl: Longterm effects of popular dietary approaches on weight loss and features of insulin resistance. Int J Obes (Lond) 2006, 30:342-349.

35. Sacks FM, Bray GA, Carey VJ, Smith SR, Ryan DH, Anton SD, McManus K, Champagne CM, Bishop LM, Laranjo N, et al: Comparison of weight-loss diets with different compositions of fat, protein, and carbohydrates. $N$ Engl J Med 2009, 360:859-873.

36. Wycherley TPBG, Clifton PM, Noakes M: Comparison of the effects of 52 weeks weight loss with either a high-protein or high-carbohydrate diet on body composition and cardiometabolic risk factors in overweight and obese males. Diabetes: Nutrition and; 2012:2

37. Wolfe BM, Giovannetti PM: Short-term effects of substituting protein for carbohydrate in the diets of moderately hypercholesterolemic human subjects. Metabolism 1991, 40:338-343.

38. Hu T, Mills KT, Yao L, Demanelis K, Eloustaz M, Yancy WS Jr, Kelly TN, He J, Bazzano LA: Effects of low-carbohydrate diets versus low-fat diets on metabolic risk factors: a meta-analysis of randomized controlled clinical trials. Am J Epidemiol 2012, 176(Suppl 7):S44-54.

39. Hession M, Rolland C, Kulkarni U, Wise A, Broom J: Systematic review of randomized controlled trials of low-carbohydrate vs. low-fat/low-calorie 
diets in the management of obesity and its comorbidities. Obes Rev 2009, 10:36-50.

40. Friedman AN, Ogden LG, Foster GD, Klein S, Stein R, Miller B, Hill JO, Brill C, Bailer B, Rosenbaum DR, Wyatt HR: Comparative effects of lowcarbohydrate high-protein versus low-fat diets on the kidney. Clin J Am Soc Nephrol 2012, 7:1103-1111.

41. Mente A, de Koning L, Shannon HS, Anand SS: A systematic review of the evidence supporting a causal link between dietary factors and coronary heart disease. Arch Intern Med 2009, 169:659-669.

42. Fung TT, van Dam RM, Hankinson SE, Stampfer M, Willett WC, Hu FB: Low-carbohydrate diets and all-cause and cause-specific mortality: two cohort studies. Ann Intern Med 2010, 153:289-298.

43. Lagiou P, Sandin S, Weiderpass E, Lagiou A, Mucci L, Trichopoulos D, Adami HO: Low carbohydrate-high protein diet and mortality in a cohort of Swedish women. J Intern Med 2007, 261:366-374.

44. Trichopoulou A, Psaltopoulou T, Orfanos P, Hsieh CC, Trichopoulos D: Low-carbohydrate-high-protein diet and long-term survival in a general population cohort. Eur J Clin Nutr 2007, 61:575-581.

doi:10.1186/1475-2891-12-48

Cite this article as: Schwingshackl and Hoffmann: Long-term effects of low-fat diets either low or high in protein on cardiovascular and metabolic risk factors: a systematic review and meta-analysis. Nutrition Journal 2013 12:48.

\section{Submit your next manuscript to BioMed Central and take full advantage of:}

- Convenient online submission

- Thorough peer review

- No space constraints or color figure charges

- Immediate publication on acceptance

- Inclusion in PubMed, CAS, Scopus and Google Scholar

- Research which is freely available for redistribution 